\title{
DESERTION, A CONTINUING OMISSIVE OFFENSE
}

\author{
Mari - Claudia IVAN \\ University of Bucharest, Faculty of Law, Romania \\ mariclaudia_i@yahoo.com
}

\begin{abstract}
In the study, the author analyzes the offense of desertion, based on its features, on the constitutive elements of its legal contents and other essential conditions required by the crime. Being a crime by omission, the desertion is committed by not doing activities which are ordered by law ("passivity to legal orders").
\end{abstract}

Keywords: desertion, offense, commissive offense, omissive offense, inaction, continuing.

\section{General considerations}

Among the fundamental social values protected by criminal law, a crucial place is also held by the country's defense capability, an important guarantee for the key attributes of the State: unity, sovereignty and independence[1].

The act of desertion is presented in the first chapter ("Offenses committed by military personnel") of Title XI, entitled "Crimes against the fighting capacity of the combat forces" in the Special Part of the Criminal Code.

The offense of desertion, in fact, is the act of unjustified absence from the unit or from work, for more than 3 days, of any military individual; it shall be punished with imprisonment from 1 to 5 years or a fine. Besides, there are also provided two aggravated forms of the crime. [art. 414 paragraph (2) and (3) of the Criminal Code].

Noting the legal definition of the crime, we find that this act is subject to the criminal law, although it represents a violation of labor relations. If we were to refer to crimes committed by any public officer in exercising their function or connected to it, we would find that there is a criminal penalty for more serious offenses that could be committed by them (for example: taking bribes - art. 289 of the Criminal Code, paying bribes - art. 290 of the Criminal Code, dilapidation - art. 295 of the Criminal Code, and so on). The mere unjustified absence from work would constitute a disciplinary offense, that may be punished by: a written reprimand, reduction of wages by $5-20 \%$ for a period of up to 3 months, suspension of the right to progress on the pay scale or, if applicable, to be promoted in the public service for a period of 1 to 3 years, demotion in the public service for a period of up to a year, dismissal from the public service [2].

However, we must not lose sight of the offense of unjustified absence (art. 413 of the Criminal Code), where the unauthorized absence of any military individual from the unit or from work, that exceeds 4 hours, but no longer than 24 hours, shall be punished only if it is committed in times of war, during a state of siege or a state of emergency. The act of unauthorized absence from work, for up to 24 hours, would be considered a deviation from the military discipline, if it is not an offense (art. 49 of the Regulation of 
military discipline [3]). When the act is committed by military personnel, they may be subject to one of the following disciplinary sanctions: warning, written reprimand, demotion in public service, delaying the promotion to the next military rank for 1-2 years, transfer in reserve (art. 51 of the Regulation of military discipline).

\section{Background circumstances}

The offenses committed by military personnel (Chapter I of Title XI), along with the offenses committed by military or civilian individuals (Chapter II of Title XI) have as their common or generic legal object social relationships relating to the combat capability of the armed forces. The specialized literature shows that the social value of the defense capacity of a country has several components which, in turn, have the character of social values such as: the country's armed forces, seen in their physical existence, in their fighting strength, the military order and discipline, the soldiers' brave behavior on the battlefield, the moral unity of the population and its spirit of resistance, the loyal and dedicated attitude of citizens towards the national defense obligations [4].

The specific legal object of the offense of desertion is represented by the social relationships relating to the obligation of the military individuals to be permanently present to work or in the military unit. These social relationships are supplemented by the requirements of military order and discipline imposed by: the Regulation of military discipline approved by the Order of the Minister of National Defence no. 64/2013, Law no. $80 / 1995$ on the status of the military personnel, the Romanian Constitution, republished, etc.

The offense has no material object.

The active subject of the offense is justified by the fact that the perpetrator must have military capacity, regardless of the rank that they hold. We believe that the military individual in question must be active (not amongst those placed in reserve [5], removed from the military records or retiring [6]), exercising their function in a unit or service (therefore not on vacation or justifiably missing from the unit or from work). In addition, this quality of the active subject is also to be found in the person of the students in military higher educational institutions, military school students and concentrated or mobilized reservists [7]. We must emphasize that regarding the offense of unjustified absence (art. 413 of the Criminal Code) it has also been asserted the opinion that one cannot have the quality of an active subject if they are short-term military personnel or students in higher education military schools [8].

This quality required by the incrimination rules becomes a "condition for the existence of the crime [9]", that once it is not met, the obligation to be present at work or in the unit is no longer required (there is no offense). One can also note that the citizen, who is not a military individual, under certain conditions, may commit the offense of evading from military registration (art. 434 of the Criminal Code), or failure to respond to conscription or concentration (art. 435 of the Criminal Code).

Last but not least, we consider that the military individual is a public official [10].

On the other hand, although according to the old Criminal Code (since 1969) the offenses of unjustified absence and desertion in the criminal doctrine were considered to be singular offenses or unique active subject offenses [11], accomplicing not being possible, however, in the current Criminal Code, the legislator incriminated the offense of desertion (but not the unjustified absence, it remaining a singular offense) as being committed by two or more military persons in a single aggravated form of the offense [art. 414 paragraph (2) letter a) of the Criminal Code]. Thus, whenever the offense of desertion is committed by two or more persons (accomplices), it does not change 
the type of the offense in the continuous form of the natural unit of offense, but it is considered in charge of each person the one and the same offense of desertion in aggravated form.

This form of criminal participation is required a condition: namely, that the perpetrators cooperate for the entire duration of the criminal activity until the exhaustion of the offense [12]. In addition, the aggravated form may also be considered if one military individual is unjustifiably missing from the unit for more than 3 days, but during this time their absence is covered by another military accomplice, because in this case, the offense has been committed by the two of them, together, even if only the first performed acts of execution, while the second confined to concomitant complicity [13].

Under these circumstances one can say that criminal participation in the offense of desertion is possible in all its forms.

The passive subject of the offense is the unit or the military service whose activity has been jeopardized through the perpetration of the offense [14].

\section{The constitutive content}

Within the objective side, we analyze the material element of the offense of desertion, its immediate consequence and their causal relation.

The material element of the offense of desertion results from the expression of the incrimination rules, that is "unjustified absence". Thus, this offense is committed whenever a military individual is unjustifiably absent from work or from the military unit, violating the military order and discipline.

The military discipline, that is the strict compliance of the military personnel with the order and rules established by the military laws and regulations, requires that every military individual be permanently present to work or in the unit in order to strictly fulfill the tasks deriving from the combat training program [15].
In relation to the objective side, in the criminal doctrine the offenses have been divided into commissive offenses and omissive offenses. They differ from one another to the extent to which the materiality of the offense is achieved, whether by carrying out an activity forbidden by law, or by abstention from an activity ordered by law [16]. Thus, in the event of a commissive offense, the perpetrator performs an action that is forbidden by law [an example would be the offense of murder (art. 188 of the Criminal Code), where the order of the law is given by the expression: "Do not kill!", the perpetrator does not comply with it, committing a "murder"] while in case of omissive offenses, the perpetrator does not perform an action that is compelled to undertake under the law [for example, the crime of family abandonment (art. 378 of the Criminal Code), where although the legislator requires to be met all the legal obligations regarding family support, the perpetrator does not respect them, remaining passive - through action or inaction - and thus carrying out an "abandonment"] [17].

Therefore the legislator orders that the military personnel strictly fulfill the tasks deriving from the combat training program [18]", do not remain passive and be present to work and in the military unit. Passivity to legal order in this crime and in the offense of unjustified absence (art. 413 of the Criminal Code), is represented precisely by the unjustified absence from work or from the unit. Absence can be achieved either through action (leaving without approval), or through inaction (failure to be present at work or in the unit). Thus, just like the offense of unjustified absence (art. 413 of the Criminal Code), the offense of desertion, depending on the manner it is performed, is either proper omissive offense (when the criminal activity is achieved by omission, that is inaction) or improper omissive offense (if the act is committed by commission, that is action). 
On the other hand, in this context there are also omissive crimes acts such as: violation of confinement (art. 415 of the Criminal Code), failure to take the necessary measures in naval operations (art. 426 of the Criminal Code), failure to respond to conscription or concentration (art. 435 of the Criminal Code).

The offense of desertion may be committed in two ways: either by leaving from work or from the unit in illegal conditions; or by failure to be present to work or in the unit within the term provided by law [19].

The absence conditions are: to exceed 3 days, to be unjustified, to be absence from the unit or from work. On the other hand, in order to commit the offense in its aggravated forms, there are to be fulfilled the following absence conditions: to hold a military gun [art. 414 paragraph (2) letter b) of the Criminal Code], to be carried out during the missions outside the Romanian territory [art 414 paragraph (2) letter c) of the Criminal Code], to exceed 24 hours in times of war or on a territory that has been proclaimed under a state of siege or emergency [art. 414 paragraph (2) letter c) of the Criminal Code].

The continuing offense is the form of the natural unit of offense, where the criminal activity consisting of a single action continues in time or takes time until the intervention of the perpetrator or the authority, that interrupts that activity [20]. In other words, the continuing offense is characterized by committing a single lasting criminal act (a single action or inaction). So the offense of desertion is an act that takes the continuous form of the unit of offense because its execution takes time, the offense is committed every time the unjustified absence exceeds 3 days. We believe that in the case of a person's activity consisting of an unjustified absence, the duration of the offense (it can also take 5 minutes, representing in this situation a disciplinary offense) cannot change its nature, it is and still remains a continuing offense (whether covered by criminal law or representing a disciplinary offense), because it involves since the beginning of its execution an existence in time.

If we were to consider that the offense is continued only after the absence exceeds 3 days, the activity carried out during the 3 days in question (constituting a disciplinary offense or in certain circumstances an offense of unjustified absence) should be considered a momentary or instantaneous act. As shown in the classification of the offenses by their objective side, the momentary (instantaneous) offenses differ from the continuing offenses as opposite types of crimes. The offense is instantaneous when the material element of the crime is committed by itself, through the very commission of the crime, and, on the contrary, it is continuing when its material element is extended in time, extension that will not end except through a new event. Hence, what is extended in time is the act itself, not the consequences [21]. Therefore, the activity carried out during the 3 days in question may by no means be characterized as instantaneous, as it is not consuming by itself, on the contrary, it requires the person concerned to terminate it, involving a development in time (in order to reach the period required by the rules of incrimination and implicitly to arise the offense).

In the specialized literature, there is a difference between the permanent continuing offenses and the successive continuing offenses. A successive continuing offense is when the criminal activity is a succession of natural interruptions determined by the nature of the criminal activity (for example: driving a vehicle without a license), while a permanent continuing offense is characterized by an uninterrupted conduct of criminal activity not requiring the perpetrator's intervention to extend the criminal activity [22]. Therefore, the offense of desertion is a permanent continuing offense. This feature is also common for other crimes, such as: the 
unjustified absence (art. 413 of the Criminal Code), leaving the post or the order (art. 416 of the Criminal Code), leaving the vessel (art. 424 of the Criminal Code), evading from military registration (art. 434 of the Criminal Code), or failure to respond to conscription or concentration (art. 435 of the Criminal Code) etc.

According to the opinion of Massari and of professor Vintilă Dongoroz the continuing offenses have an objective element that is achieved through a double attitude, a commissive one (sequestration of a person) followed by another omissive act (not letting go of that person) [23]. The same for the offense subject to our analysis, the only difference being that the objective element of desertion can be done either by commission (leaving the unit or the military service) or by omission (failure to be present in the unit or at work) and the activity carries out in time by omission (passivity to continue to fail to comply with the legal order).

The immediate consequence is to create a state of danger for the proper operation of the unit or the military service, which through unjustified absence could weaken the combat capability of the armed forces.

The causal relation emerges from the very materiality of the fact.

As regards the subjective side, we believe that the offense of desertion can be committed with one of the methods of the intention: directly or indirectly.

Although the purpose and the reason one commits the offense of desertion have no legal relevance, however, they are taken into account when individualizing the sentence. In practice, it has been decided that there is desertion, even if the defendant failed to be present in the unit from the $31^{\text {st }}$ of May 1997 until the $2^{\text {nd }}$ of June 1997 in order to inquire about the health condition of the victim that they had injured in a car accident, believing that they were in a critical condition [24].
As a continuing offense, the offense of desertion is consumed on the expiration of the 3-day term, and this state of absence is maintained until the military deserter voluntarily returns to the unit, surrenders to the legal authorities, is brought to the unit by the public power or is convicted in the first instance. In times of war, during a state of siege or of emergency, the offense of desertion is consumed on the expiration of the 24-hour term, until this deadline, the act constituting the offense of unjustified absence (of course, if the absence lasted more than 4 hours). The offense of desertion is considered depleted when the absence which constitutes the material element of the act ends by one of the means shown above [25].

There are different opinions about the situation of those military individuals who are absent from the unit several times, but they meet each time the conditions required by art. 414 of the Criminal Code. In doctrine there was reasoned that in such circumstances there can only be a plurality of desertions, not a single continuing offense of desertion because the act of desertion typically involves a new criminal resolution determined by circumstances and new situations. In legal practice there was decided, however, that repeated acts of desertion performed at short intervals of time constitute a single (continuing) offense because it would be based on the same criminal resolution [26].

The offense of desertion is typically punishable by imprisonment from 1 to 5 years or with a fine, in the first aggravated form by imprisonment from 3 to 10 years, in the second aggravated form by imprisonment from 3 to 10 years.

In conclusion, we can state that the offense of desertion is an omissive and also continuing offense, and it may also take the continuous form, as decided in the legal practice. 


\section{References}

[1] O. Loghin, T. Toader, Criminal Law. The Special Part, revised and enlarged edition, Bucharest, ,Șansa” S.R.L. Media and Publishing House, 1996, page 607.

[2] Law no. 188/1999 on Public Service Regulations, with the subsequent amendments and supplements.

[3] With reference to the Order of the Minister of National Defence no. M.64/2013 for the approval of the Regulation of military discipline (published in the Romanian Official Gazette, Part I, no. 399 dated 3rd of July 2013).

[4] O. Login, T. Toader, cited work, page 607.

[5] Under art. 4 letter b) of Law no. 80/1995 on the status of the military personnel in reserve, when they do not occupy military positions, but they meet the conditions provided by law in order to be called for military service as concentrated or mobilized reservists, and, when needed, as active military personnel.

[6] Under art. 4 letter c) of Law no. 80/1995, the military personnel is in retreat, when, according to the law, they can no longer be called for military service.

[7] O. Loghin, T. Toader, cited work, page 613. Likewise, V. Dobrinoiu, M.A. Hotca, M. Gorunescu, M. Dobrinoiu, I. Pascu, I. Chiș, C. Păun, N. Neagu, M. C. Sinescu, Comments on the New Criminal Code. The Special Part, 2nd edition, Bucharest, Universul Juridic Publishing House, 2014, page 1040.

[8] O. Login, T. Toader, cited work, page 610. Otherwise, V. Dobrinoiu et al, cited work, page 1035 .

[9] V. Dongoroz, Criminal Law, Reediting of the 1939 edition, Bucharest, Tempus Society \& The Romanian Association of Criminal Sciences Publishing House, 2000, page 167.

[10] In addition, refering to the provisions of art. 175 of the Criminal Code, the public officer is defined as the person who, permanently or temporarily, with or without remuneration, is either carrying out duties and responsibilities established by law in order to achieve the prerogatives of the legislative, executive or judicial power, or exercising a public dignity position or a public position of any kind, exercising alone or jointly with other people, in an autonomous administration, or another economic operator or a legal entity whose capital is wholly or in majority owned by the State, tasks related to achieving the object of its activity. On the other hand, there is considered a public officer for the purposes of criminal law, a person exercising a public service which was granted by the public authorities or is subject to their control or supervision regarding the achievement of the public service in question. Also refer to Gh. Ivan, M.-C. Ivan, Criminal Law. The Special Part according to the new Criminal Code, 2nd edition, Bucharest, C.H. Beck Publishing House, 2015, pages 320-330.

[11] With reference to the classification of the offenses by the number of people who can commit them, in collective and singular offenses (V. Dongoroz, cited work, page 167).

[12] With reference to M.A. Hotca (coord.), M. Gorunescu, N. Neagu, R.-F. Geamănu, M. Dobrinoiu, M. C. Sinescu, R. Slăvoiu, L.-D. Al-Kawadri, C. Nedelcu, A. Hărătău, The New Criminal Code. Notes, Correlations, Explanations, Bucharest, C. H. Beck Publishing House, 2014, page 714.

[13] M.A. Hotca (coord.) et al, cited work, pages 714-715.

[14] V. Dobrinoiu et al, cited work, page 1041.

[15] O. Loghin, T. Toader, cited work, page 610.

[16] V. Dongoroz, cited work, page 250.

[17] See for explanation M.-C. Ivan, Commissive Offenses and Omissive Offenses, in European legal studies and research, Timișoara, Romania, Universul Juridic Publishing House, 2015, page 310 . 
[18] O. Loghin, T. Toader, cited work, page 610.

[19] V. Dobrinoiu et al, cited work, page 1041.

[20] I. Oancea, Criminal Law. The general part, Bucharest, Didactic and Pedagogical Publishing House, 1971, page 219.

[21] V. Dongoroz, cited work, page 251.

[22] C. Mitrache, Cr. Mitrache, Romanian Criminal Law. The general part, Bucharest, Universul Juridic Publishing House, 2014, pages 301-302.

[23] V. Dongoroz, cited work, page 251.

[24] V. Dobrinoiu et al, cited work, page 1043.

[25] Ibidem.

[26] Ibidem, page 1044. 